\title{
Calcretes e registros de paleossolos em depósitos continentais neocretáceos (Bacia Bauru, Formação Marília)
}

\author{
Luiz Alberto Fernandes ${ }^{1}$
}

\begin{abstract}
Resumo Os resultados apresentados baseiam-se em estudo regional de calcretes e registros de paleossolos da parte oriental da Bacia Bauru, em São Paulo e Triângulo Mineiro. Esta bacia neocretácea foi preenchida por seqüência siliciclástica arenosa única, em clima semi-árido nas bordas, desértico no centro. Os calcretes mais expressivos estão na Formação Marília (Grupo Bauru) que, em escala regional, são representados por dois tipos extremos, relacionados com o contexto deposicional. O Ponte Alta formou-se em depósitos de leques aluviais marginais, o tipo Echaporã, em depósitos arenosos eólicos interiores, de extensos lençóis de areia e suaves depressões com rios e lagoas temporários. São propostos três contextos genéticos para os calcretes da Formação Marília: pedogenético periférico $(\mathrm{Pp})$, pedogenético interior $(\mathrm{Pi})$ e freático $(\mathrm{F})$. Nos dois primeiros predominaram processos edáficos vadosos e paludiais, perfis de solos pouco desenvolvidos. Neles verificouse maior freqüência da associação de microtexturas beta. Ocorrem no Triângulo Mineiro (MG), regiões de Monte Alto, Agudos, Bauru (SP). No contexto freático houve intenso desenvolvimento de texturas micríticas a esparíticas, que provavelmente destruiu feições originais da associação beta, geradas em contextos Pp e Pi. A sobreposição de processos freáticos determinou predomínio da associação de microtexturas alfa. Eles foram provavelmente mais intensos e do último e/ou do mais importante evento na formação dos calcretes internos da bacia, em perfis tipo Echaporã. Ocorrem nas regiões de Marília e Echaporã (SP). A configuração dendrítica do relevo de platôs estritos e longos, sustentados pelos arenitos calcificados da Formação Marília, indica processos de elaboração da paisagem por inversão de relevo.
\end{abstract}

Palavras-chave: calcretes, paleossolos, Marília, Bauru, inversão de relevo.

\begin{abstract}
Calcretes and palaeosol records on upper cretaceous continental deposits (Bauru Basin, Marilia Formation). The results presented are based on regional research of calcrete and palaeossols records in the Eastern part of the Bauru Basin, in São Paulo State and Triângulo Mineiro region. This basin was filled by Upper Cretaceous siliciclastic sandy sequence, in semi-arid climate on the edges, desert in the center. The most significant calcretes occurrences belong to the the Marilia Formation (Bauru Group), whichon a regional scale, are represented by two extreme types, related to the depositional context. The Ponte Alta type was formed in marginal alluvial fan deposits, the Echaporã type in inner aeolian sandy deposits, of wide sand sheets and smooth depressions with temporary rivers and lakes. Three genetic contexts are proposed for the Marilia Formation calcretes: pedogenetic peripheral $(\mathrm{Pp})$, pedogenetic interior $(\mathrm{Pi})$ and phreatic $(\mathrm{F})$. In the first two contexts the edaphic vadose and palustrine processes prevailed, as well as soil profiles poorly developed. It was noticed in them a big frequency of the beta microstructure association. They occur in the Triângulo Mineiro (MG), regions of Monte Alto, Agudos and Bauru (SP). In the phreatic context there was intense development of micritic and spar textures, which probably destroyed the original features of the beta association, generated in contexts Pp and Pi. The superimposed phreatic processes determined the predominance of the alpha microstructure association. They were probably more intense and of the last and/or the most important event in the internal calcrete formation of the basin,in Echaporã type profiles. They occur in the regions of Echaporã and Marília (SP). The dendritic configuration of the long and narrow plateaux, sustained by calcified sandstones of the Marília Formation indicates processes of landscape elaboration through the relief invertion.
\end{abstract}

Keywords: calcretes, palaeosols, Marília, Bauru, relief invertion.

CONSIDERAÇÕES INICIAIS O estudo de paleossolos e calcretes (estratos calcificados, com nódulos ou crostas carbonáticas) constitui ferramenta eficaz na análise paleoambiental e de evolução de bacias sedimentares. Solos e paleossolos refletem complexa inter-relação entre sedimentação, erosão, não-deposição, assim como graus de pedogênese. Comumente, paleossolos corres- pondem a empilhamento vertical de eventos. A partir do início dos anos 80 verificou-se notável aumento do interesse no estudo do desenvolvimento dos paleossolos associados com calcretes. Boas revisões sobre tal evolução e definição de conceitos podem ser encontradas, por exemplo, em Kraus (1999) e Alonso-Zarza (2003).

Paleossolos expressam efeitos das condições

1 - Universidade Federal do Paraná, Departamento de Geologia, Laboratório de Estudos Sedimentológicos e Petrologia Sedimentar (LabESed-UFPR), Curitiba (PR), Brasil e Bolsista de Produtividade em Pesquisa do CNPq. E-mail: lufernandes@ufpr.br 
ambientais que prevaleceram, ou ainda prevalecem, no ambiente deposicional. Além disto, permitem identificar episódios pedológicos, a existência de eventuais hiatos deposicionais, intervalos para correlação estratigráfica, estimar taxas de sedimentação ou ainda, discutir padrões evolutivos de planícies de inundação e relevo. $\mathrm{O}$ topo de um paleossolo pode ser caracterizado como a descontinuidade - erosiva ou não - abaixo da qual há registros de bioturbação por raízes e outros organismos. Wright (2007) definiu calcretes como denominação geral de acumulações terrestres próximas da superfície, predominantemente de carbonato de cálcio, que ocorrem de forma variada: pulverulento, nodular, laminar e maciço.

No caso da Bacia Bauru, a cimentação carbonática foi característica valorizada por muito tempo na sua compartimentação litoestratigráfica. Tal critério foi importante na distinção e correlação entre unidades litológicas geograficamente separadas e distantes, utilizado desde os primeiros ensaios de subdivisão da cobertura suprabasáltica (e.g. Setzer 1943, 1948; Almeida \& Barbosa 1953). Influiu nos modelos estratigráficos e, conseqüentemente, nos da evolução geológica da bacia. Hasui (1969), todavia, apontou a impossibilidade de aplicar a cimentação carbonática na correlação estratigráfica regional. Comparou a Formação Bauru - designação da então indivisa seqüência neocretácea-, de São Paulo com a do Triângulo Mineiro. Tratou-as como mesma unidade, indistinta, por falta de horizontes-guia de caráter regional e de diferenças claras quanto à disposição das camadas cimentadas e não cimentadas.

Suguio \& Barcelos (1983) afirmaram que a maioria das rochas carbonáticas encontradas nas unidades da Bacia Bauru são calcretes. Estudos mais recentes, como discutido adiante, têm indicado que a cimentação carbonática resulta de processos diversos, pedogenéticos, freáticos e diagenéticos, às vezes múltiplos e sobrepostos, a que foram submetidos os sedimentos até chegarem ao estado apresentado atualmente.

Os resultados ora apresentados constituem revisão de estudo de caráter regional de calcretes e registros de formação de paleossolos em unidades da parte oriental da Bacia Bauru, sobretudo da Formação Marília, obtidos por Fernandes (1998). As investigações referem-se principalmente ao centro-oeste de São Paulo e Triângulo Mineiro. Os critérios básicos de caracterização dos paleossolos em campo foram: identificação de horizontes cimentados, feições e texturas pedogênicas, bioturbações e eventuais depósitos de pavimentos de deflação associados. No estudo da mineralogia, microtexturas, petrofácies sedimentares e pedogênicas foram analisadas 30 seções delgadas de rochas com microscópio óptico de luz transmitida. Algumas vezes utilizou-se de microscopia eletrônica de varredura (MEV) para identificação complementar de hábitos, texturas e relações de componentes diagenéticos com arcabouço, matriz e espaços intergranulares.

CONTEXTO GEOLÓGICO E EVOLUÇÃO SEDIMENTAR A Plataforma Sul-Americana manteve o caráter ascensional iniciado antes da separação do
Gondwana até que o peso dos basaltos acumulados determinasse inversão de tal comportamento, na busca de nova condição de equilíbrio isostático. A Bacia Bauru constituiu depressão formada no interior da plataforma, neste movimento subsidente de ajuste isostático, ocorrido após acúmulo de quase $2.000 \mathrm{~m}$ de derrames basálticos da Formação Serra Geral (Fernandes \& Coimbra 1996). Foi preenchida por seqüência siliciclástica psamítica única, em condições semi-áridas nas bordas a desérticas no centro.

O substrato basáltico aonde se estabeleceu a nova bacia permaneceu assim exposto até que a elevação do nível de base regional permitisse acumular sedimentos no interior da placa Sul-Americana, apenas no Cretáceo Superior. A seqüência suprabasáltica neocretácica (SSN) ocorre hoje em área aproximada de 370.000 $\mathrm{km}^{2}$, nos estados de Minas Gerais, São Paulo, Paraná, Mato Grosso do Sul, Goiás e Mato Grosso; nordeste do Paraguai (Fig. 1). Tem espessura atual máxima preservada de cerca de 480 metros, no noroeste do Paraná.

O início da sedimentação na bacia corresponde ao sepultamento progressivo do substrato basáltico por extensa e monótona manta arenosa, formada principalmente por lençóis de areia com dunas baixas, interdunas e depressões eventualmente úmidas ou aquosas, onde lamas foram retidas. Sobretudo nas áreas mais marginais, as amplas planícies eram atravessadas por fluxos esporádicos não-confinados de enxurradas de deserto (wadis). No eixo central da bacia endorrêica ajustou-se um sistema regional de drenagem, vindo de suas bordas, rumo à periferia do deserto interior Caiuá, quente e seco.

Uma segunda fase de preenchimento teve início após eventos de elevação das bordas da bacia, acompanhados pela instalação de corpos ígneos de natureza alcalina em altos tectônicos marginais do embasamento. $\mathrm{O}$ único registro de magmatismo extrusivo sinsedimentar, de analcimitos denominados Taiúva, situa-se próximo da atual borda leste da bacia. Fernandes et al. (1993) relacionaram tal vulcanismo aos eventos ígneos citados, assim como a silicificação de arenitos situados no cruzamento de grandes estruturas tectônicas regionais de direção nordeste com o Arco de Ponta Grossa, no sul da bacia.

Em termos litoestratigráficos a SSN é composta pelos grupos Caiuá e Bauru. O primeiro compreende as formações Rio Paraná, Goio Erê e Santo Anastácio. O segundo reúne as formações Uberaba, Vale do Rio do Peixe, Araçatuba, São José do Rio Preto, Presidente Prudente e Marília, além de rochas vulcânicas alcalinas intercaladas, os Analcimitos Taiúva (Fig. 1).

A sedimentação na Bacia Bauru ocorreu em condições semi-áridas, mais úmidas na periferia e desérticas no interior (Fig. 2). Na região de Uberaba (MG) preservaram-se registros dos depósitos mais proximais originais da parte oriental da bacia: associações de fácies areno-conglomeráticas, de leques aluviais e sistemas fluviais entrelaçados distributários associados. Em termos litoestratigráficos tais depósitos correspondem aos membros Serra da Galga e Ponte Alta da Formação Marília. Fora desta região, a única ocorrência de depósitos psefíticos conhecida na porção leste da 


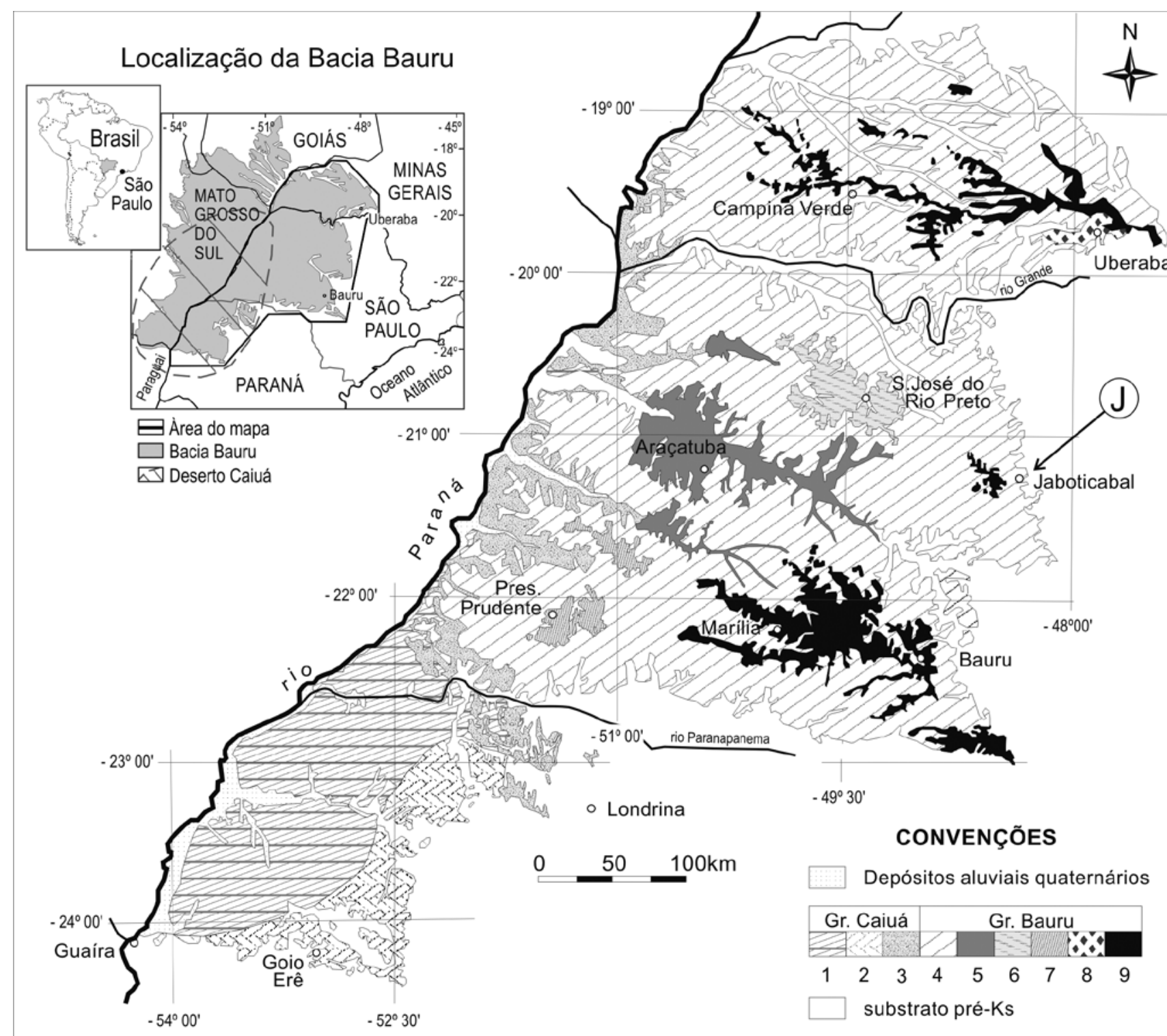

Figura 1 - Mapa litoestratigráfico da parte oriental da Bacia Bauru.

bacia situa-se próxima à cidade de Botucatu (SP). Foram designados de Litofácies Rubião Jr. (Fernandes 1998) e incluídos na Formação Marília. O retrabalhamento, sobretudo eólico das porções distais de leques aluviais formou grandes planícies de lençóis de areia (Basilici et al. 2007), em parte dos quais se desenvolveu intensa cimentação carbonática. Os arenitos cimentados, produtos destes processos, correspondem ao Membro Echaporã da Formação Marília. Durante o preenchimento da bacia a drenagem regional sempre teve caráter endorrêico. Entre as bordas úmidas e o interior desértico seco, formaram-se depósitos de rios entrelaçados a meandrantes arenosos. Inicialmente mantiveram região pantanosa interior (Fernandes \& Basilici 2009), correspondente à Formação Araçatuba, que depois foi encoberta por depósitos de extensos e monótonos lençóis de areia, em que se intercalam depósitos de dunas baixas, loesse e wadis (Formação Vale do Rio do Peixe), unidades expostas nos principais vales atuais nas partes mais internas da bacia.

As extensas planícies de lençóis de areia eram atravessadas por sistemas fluviais entrelaçados de rumo geral para sudoeste (Formação São José do Rio Preto) que se transformavam em sistemas fluviais meandrantes arenosos finos, de canais rasos (Formação Presidente Prudente). Até desfazerem-se gradualmente nas proximidades do grande deserto interior, quente e seco, denominado Caiuá (Fernandes \& Coimbra 2000). Nesta porção desértica da bacia predominaram lençóis de areia secos (Formação Santo Anastácio); que passavam a depósitos de dunas eólicas médias e interdunas úmidas, zona periféricas de sand sea (Formação Goio Erê); e a complexos de dunas eólicas de grande porte (draas), parte central de sand sea interior (Formação Rio Paraná).

Nas regiões de Marília e Monte Alto (SP), assim como no Triângulo Mineiro (MG) encontra-se a maior diversidade de registros fossilíferos da Bacia Bauru, as- 


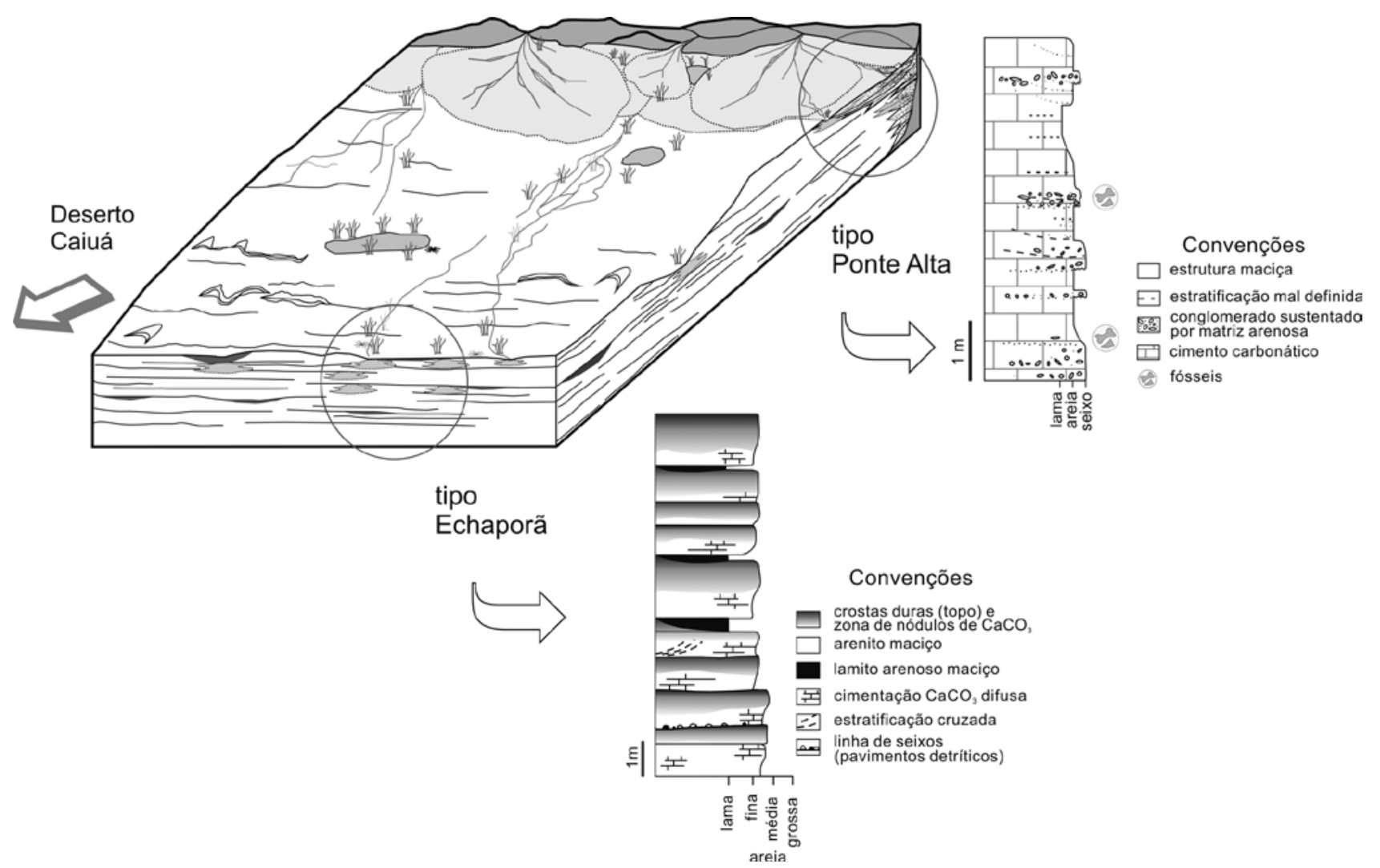

Figura 2 - Cenário paleoambiental da porção centro-norte da Bacia Bauru, com o contexto genético dos dois principais tipos de calcretes, designados Ponte Alta e Echaporã.

sim como os indivíduos de maior porte. Esta concentração coincide aproximadamente com as zonas de maior desenvolvimento de calcretes. Certamente a maior disponibilidade de água, mesmo em contexto semi-árido, favoreceu a manutenção da vida próxima às bordas $\mathrm{e}$ nas partes mais baixas no interior da bacia. Ali rios e enxurradas de deserto, com lagoas efêmeras permitiram que animais e plantas sobrevivessem. A vida,mais exuberante nestas partes úmidas, torna-se escassa rumo interior da bacia, como atestam raras ocorrências de pegadas de dinossauros terópodes e pequenos mamíferos, em estratos frontais de dunas do antigo deserto Caiuá, do interior da bacia (Fernandes et al. 2009).

CALCRETES E REGISTROS DE PALEOSSOLOS DA PARTE ORIENTAL DA BACIA BAURU De modo geral, em toda a parte oriental da bacia há vestígios de atividades biológicas e processos pedogênicos, sobretudo relacionados com deposição de cimento carbonático. Os intervalos mais cimentados (calcretes) ocorrem com maior freqüência e expressão em relevo nas zonas mais periféricas preservadas da seqüência neocretácea. Os mais espessos são arenitos intensamente cimentados do Membro Ponte Alta (Fig. 3.6 e 6.1), que ocorrem nas cercanias de Uberaba (Minas Gerais), e estratos endurecidos de arenitos cimentados do Membro Echaporã (Fig. 3.1, 3.2 e 6.2) na região de Marília, em São Paulo. Entretanto, intervalos concrecionados ou com cimentação difusa, assim como nodular ou laminar, podem ser encontrados em outras unidades da bacia. Por exemplo, no Membro Serra da Galga da Formação Marília (região de Uberaba), nas formações Vale do Rio do Peixe e São José do Rio Preto, ou mesmo em locais bastante internos da bacia, como no norte do Paraná e oeste de São Paulo, nas formações Goio Erê e Santo Anastácio (Fig. 3.3, 3.5, 3.7 e 7.5).

Moldes de raiz são mais freqüentes em depósitos relacionados com ambientes aquosos, correspondentes aos deposicionais das formações Araçatuba, Presidente Prudente e São José do Rio Preto, no interior de São Paulo. São feições tubulares cilíndricas, preenchidas ou não por material distinto do arcabouço adjacente (p.ex. Fig. 7.7). Outras feições tubulares de origem indeterminada, se vestígios de raízes ou de escavações de pequenos organismos, foram descritas nas formações Marília (Membro Echaporã), Vale do Rio do Peixe e Santo Anastácio (Quadro 1).

Estruturas de raiz indicam condições paleoambientais para desenvolvimento de horizontes edáficos (paleossolo). Indicam baixa taxa de sedimentação, para que os depósitos permanecessem expostos e colonizados por plantas, assim como existência de contexto vadoso subaéreo. Concentrações de outras feições como perfurações e orifícios de origem indeterminada também podem indicar intervalos edáficos, sobretudo se limitadas no topo por superfície subhorizontal. As raízes podem espalhar-se lateralmente sobre crostas duras e alguns tipos de raízes ramificam para cima e para fora 

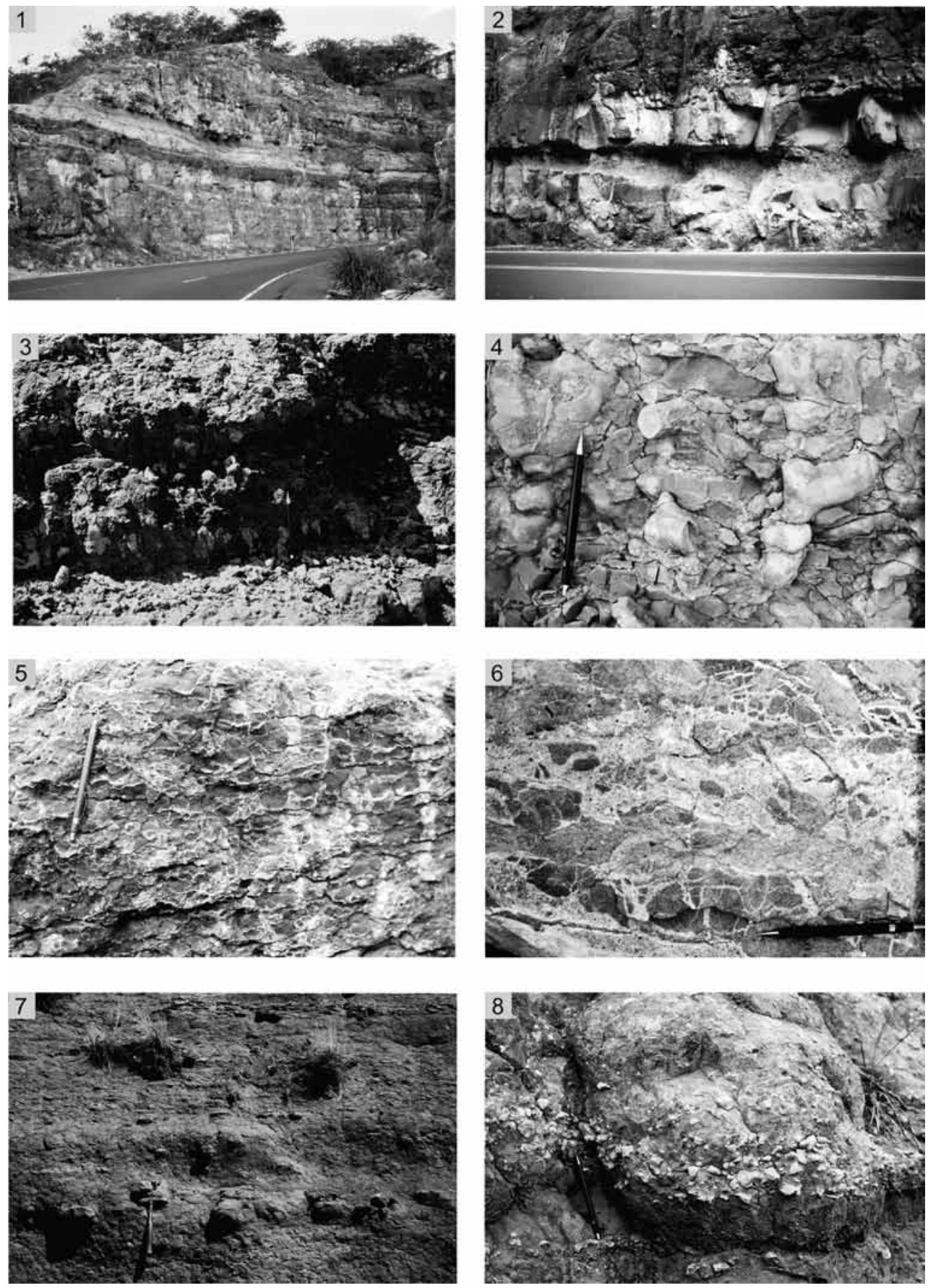

Figura 3 - 1) Seção-tipo do Membro Echaporã: estratos de arenito de maciço com cimento carbonático; com lentes de lamitos arenosos intercaladas. Local: Serra do Mirante, SW de Marilia (SP). O corte tem altura máxima de $12 \mathrm{~m}$; 2) Estratos arenosos tabulares, com eventuais intercalações de lentes de pelitos arenosos (topo plano e base côncava). Serra do Mirante; 3) Calcrete pedogênico em depósitos de arenitos maciços de lençóis de areia. Formação Santo Anastácio, em corte de rodovia a NE de Palmeira d'Oeste (SP); 4) Escavações tubulares de direções diversas, preenchidas por arenito com cimento carbonático. Membro Echaporã (Formação Marília), NE de Comendador Gomes $(M G)$; 5) Horizonte laminar de calcrete pedogenético (estrutura favo de mel), em depósitos de lençóis de areia. Formação Santo Anastácio, corte do canal hidroviário de Pereira Barreto (SP); 6) Arenito imaturo intensamente cimentado, com feições de rompimento por crescimento deslocativo (displacive) de carbonato; rocha denominada pseudobrecha. Membro Ponte Alta, Pedreira do Lajeado, Serra do Veadinho, Peirópolis $(M G)$; 7) Nódulos de cimento carbonático em arenitos em depósitos de interdunas. Formação Goio Erê, a oeste da localidade homônima, noroeste do Paraná; 8) Depósito conglomerático com intraclastos carbonáticos, de retrabalhamento de calcretes, na base de horizonte nodular. Membro Echaporã, região de Marília (SP). 
Quadro 1- Feições mesoscópicas de calcretes e vestígios de paleossolos descritas na parte oriental da Bacia Bauru.

\begin{tabular}{lll}
\hline \multicolumn{1}{c}{ Feição } & \multicolumn{1}{c}{ Características } & Unidade \\
\hline & estratos arenosos tabulares de até $1 \mathrm{~m}$ de espessura, às & \\
& vezes sob depósitos de deflação c/ ventifactos. Constituem: & \\
crostas duras, intervalos nodulares, intervalos de textura & Fms. Marília (mbs. Echaporã e \\
(calcretes) & mosqueada/nebulosa ou intervalos de rocha friável. Podem & Ponte Alta) e Santo Anastácio \\
& conter feições tubulares (rizólitos ou pedotúbulos*?), & \\
preenchidos por areia e/ou $\mathrm{CaCO}_{3}($ Ver Fig. 4) & \\
\hline
\end{tabular}

contra-moldes, moldes de raízes ou escavações tubulares, preenchidos feições tubulares verticais vazias (moldes) ou preenchidas por silte/areia (contra-moldes), às vezes bifurcadas para baixo; com diâmetro milimétrico, comprimento até $12 \mathrm{~cm}$ (moldes de raízes e/ou pedotúbulos)
Fms. Araçatuba, Presidente Prudente, São José do Rio Preto e Vale do Rio do Peixe nódulos carbonáticos (autóctones) vazios preenchidos por carbonato
Fm. Marília (mbs. Echaporã e

Ponte Alta); Fm. Araçatuba nódulos argilosos
(autóctones) vazios preenchidos por material argiloso, às vezes associado a óxidos de ferro e manganês e zonas de carbonatos
Fms. Araçatuba e Presidente Prudente

*Pedotúbulo = bioturbação tubular de origem incerta, possivelmente de escavação por verme ou inseto.

do solo. Além do mais, inúmeros insetos e outros organismos escavam ao redor, ou mesmo a própria raiz, para alimentarem-se. Vestígios de raízes pobremente preservadas podem ser realçados por incrustações formadas ao seu redor, durante o crescimento. Com a remoção de $\mathrm{CO}_{2}$ da água pelas raízes as soluções tornam-se mais concentradas, podendo causar precipitação de carbonatos. A área de captação ativa de nutrientes ao redor de uma raiz (rizosfera) é uma zona gelatinosa (mucigel) rica em bactérias e fungos (Retallack 1988).

$\mathrm{Na}$ maior parte do tempo a zona de raiz tem $\mathrm{pH}$ e Eh próximos do neutro, permitindo a atividade normal de raízes e micróbios. As condições podem mudar em curtos intervalos de tempo após deficiência de chuvas ou nutrientes. Horizontes edáficos têm limites mais discretos (ou graduais) que os de acamamento sedimentar. Em geral estas mudanças graduais são subparalelas à superfície de truncamento do paleossolo (Retallack 1988). O preenchimento às vezes apresenta mais de uma etapa, com distintos depósitos concêntricos de argila, silte ou areia, carreados para o vazio deixado após a deterioração da raiz. Nas unidades estudadas foram encontrados principalmente contramoldes e moldes de raízes, classificáveis como rizólitos na acepção de Klappa (1980).

Vestígios de raízes podem ser facilmente identificados quando a matéria orgânica original foi preservada. Isto raramente ocorre em possíveis paleossolos vermelhos e variegados, como os da Bacia Bauru. Geralmente, o que resta são feições tubulares preenchidas por material distinto do adjacente, algumas vezes limitados por película de óxidos de ferro ou manganês. $\mathrm{O}$ preenchimento pode registrar várias fases de infiltração de argila, silte ou areia, carreados para o vazio deixado após a deterioração da raiz.

Dentre os vestígios de raízes identificados na Bacia Bauru são comuns contramoldes, caracterizados como túbulos preenchidos por material distinto do arcabouço, por areia ou silte, cimentados ou não. Moldes de raízes foram encontrados principalmente em litofácies mais finas, associadas a ambientes de maior umidade (pântano, lagoas ou planícies fluviais de inundação). São feições tubulares geralmente verticais, vazias ou parcialmente preenchidas, que diminuem de diâmetro - e às vezes bifurcam - para baixo. Frequentemente são limitadas por superfícies planas de topo. Têm diâmetro comum milimétrico e comprimento da ordem de $10 \mathrm{~cm}$. Podem ser revestidas por película argiloferruginosa ou por óxidos de manganês (Fig. 7.6). Poucas vezes foram encontrados túbulos preenchidos por calcita cristalina. Os contramoldes são mais comuns nas formações Santo Anastácio e Vale do Rio do Peixe, e provavelmente originaram-se pelo preenchimento de vazios tubulares ou pela precipitação de carbonato em torno de raízes. Klappa (1980) e Loope (1988) afirmaram que estruturas deste tipo desenvolvem-se em substratos planos, em sedimentos de alta permeabilidade e com disponibilidade de íons de cálcio, tais como superfícies de deflação com calcretes, em clima semi-árido. Outras feições tubulares encontradas possivelmente correspondem a escavações de organismos tais como insetos e vermes (Fig. 3.4). Geralmente possuem diâmetro maior de até $2 \mathrm{~cm}$, e são preenchidas por areia cimentada ou não por 
carbonato. Foram encontradas principalmente em depósitos de lençóis de areia (Membro Echaporã e Formação Vale do Rio do Peixe).

PERFIS DE CALCRETES DA FORMAÇÃO MARÍLIA Na metade oriental da bacia, a Formação Marília pode ser dividida duas associações principais de fácies, associadas a calcretes mais espesos. A primeira, que hoje ocorre praticamente apenas na borda nordeste, é formada por conglomerados intercalados com arenitos conglomeráticos (Fig. 6.1) e lamitos. A segunda é composta por arenitos finos a médios, imaturos, em estratos tabulares maciços de até $2,5 \mathrm{~m}$ de espessura, com lentes de lamitos maciços intercalados subordinados (Fig. 2, 4, 3.1, 3.2 e 6.2).

A primeira associação é formada por arenitos, arenitos e lentes conglomeráticas, que corresponde a depósitos de porções proximais a medianas de sistemas de leques aluviais e lagos efêmeros interleques. Nas partes mais distais destes sistemas acumularam-se unidades la- míticas com características sedimentares de contexto paludial ou lacustre efêmero, tais como composição (micritos e biomicritos com ostracodes) e ocorrência de marcas de raízes e gretas de ressecação. A segunda associação ocorre na parte mais interna da bacia. É constituída por estratos tabulares de arenitos com intercalações de lentes de lamitos maciços arenosos de base côncava e topo plano, espessura decimétrica. Esta associação corresponde a depósitos de extensos lençóis de areia, com lagoas residuais efêmeras, onde foram retidas partículas menores carreadas pelo vento ou por decantação, devido à presença temporária de água (Fernandes 1998, Mason et al. 1999). Em termos litoestratigráficos a primeira associação corresponde aos membros Serra da Galga e Ponte Alta, e ocorre no Triângulo Mineiro. A segunda corresponde ao Membro Echaporã, que sustenta os planaltos dendriformes do interior paulista e do oeste mineiro.

No Membro Echaporã podem ocorrer concentrações de clastos (Fig. 3.8) em intervalos de espessura em geral centimétrica, descontínuos, às vezes esparsos

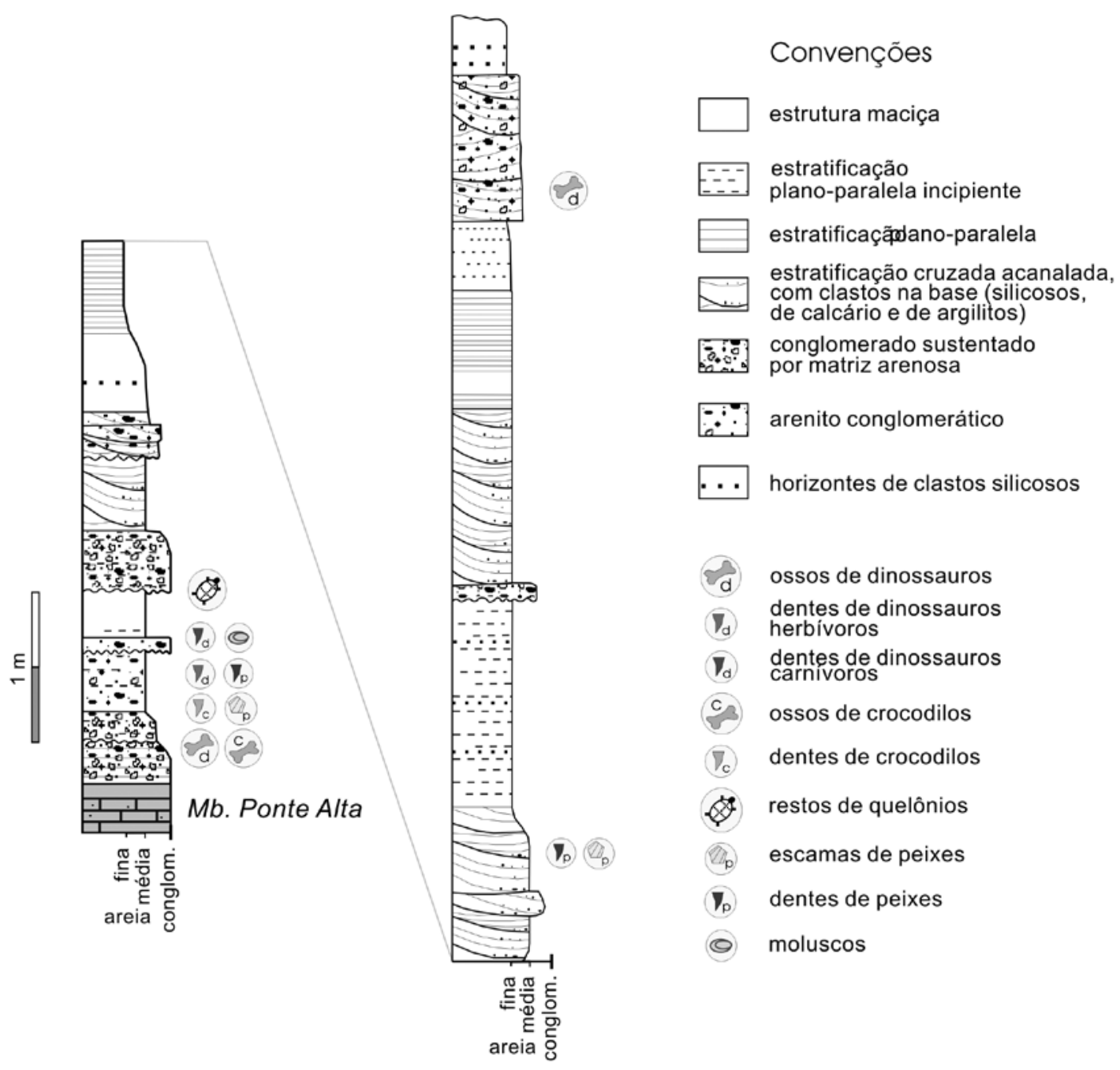

Figura 4 - Seção-tipo do Membro Serra da Galga. Serra do Veadinho, imediações de Peirópolis (Uberaba, MG). (Fernandes 1998, adapt. de Capilla \& Azevedo 1996). 
embora alinhados. São constituídos por nódulos carbonáticos, raros clastos silicosos, em geral acumulados no topo ou acima de horizontes de crostas carbonáticas. Intercalações conglomeráticas, raras no interior da bacia, são constituídas por intraclastos carbonáticos remobilizados, sendo pouco freqüentes os silicosos. A posição e forma destas intercalações conglomeráticas, em geral associadas a horizontes de calcretes, indicam tratarem-se de depósitos em pavimentos de deflação eólica e remobilização por enxurradas e fluxos em lençol, recorrentes. A preponderância de intraclastos carbonáticos decorre do fato de que derivam, sobretudo, de retrabalhamento de solos mais antigos associados a calcretes, em eventos de transporte vigorosos e pouco duradouros.

Os denominados "calcários" lavrados no Triângulo Mineiro na verdade são arenitos com intensa cimentação carbonática, em termos litoestratigráficos designados como Membro Ponte Alta. Constituem unidades tabulares intercaladas em arenitos do Membro Serra da Galga. Fernandes (1998) considerou que tal diferenciação, causada essencialmente pelo cimento carbonático, foi gerada após a deposição. Destacou que, em termos de associações de fácies sedimentares, os dois membros são muito similares. Tal concepção concorda com a posição estratigráfica da unidade Ponte Alta proposta por Goldberg \& Garcia (1995), assim como com a gênese advogada para o Membro Ponte Alta por Silva et al. (1994) de calcretes de águas subterrâneas.

Com base nos estudos realizados propõe-se aqui reunir os calcretes da Formação Marília em dois tipos genéticos principais, sobretudo por critérios paleoambientais. O tipo Echaporã desenvolveu-se nas partes mais interiores da bacia, sobre depósitos de lençóis de areia e de planícies fluviais entrelaçadas de deserto, em contexto eólico predominante. O outro, designado de Ponte Alta, desenvolveu-se sobre depósitos proximais a medianos de leques aluviais marginais. Este segundo tipo genético corresponde, em termos litoestratigráficos, aos membros Serra da Galga e Ponte Alta.

Microtexturas de calcretes da Formação Marília Os resultados ora apresentados referem-se a estudos em escala regional de unidades com calcretes da metade oriental da Bacia Bauru, principalmente dos membros Ponte Alta e Echaporã, ambos da Formação Marília (Fig. 2). A análise de cerca de 30 seções delgadas de rocha permitiu reconhecer duas petrofácies principais, com base na identificação de associações de microtexturas tipo alfa e beta (Fig. 5), definidas por Wright \& Tucker (1991).

A associação tipo alfa caracteriza-se por apresentar textura micrítica a microesparítica, com grãos detríticos sobretudo de quartzo imersos, freqüentemente de bordas corroídas, além de feldspatos e fragmentos líticos isolados (Fig. 6.3 a 6.8). A matriz carbonática às vezes pode estar intensamente recristalizada, esparítica (Fig. 6.3, 6.7 e 7.2). Feições como preenchimento de fraturas e crescimento deslocativo (displacive) de calcita são comuns nestas petrofácies (Fig. 6.4 e 7.3). Também são encontrados cristais romboédricos de calcita desenvolvidos na matriz micrítica (Fig. 7.1), assim como possíveis indícios de dolomitização. A associação alfa é mais comum em depósitos siliciclásticos modernos e antigos de contexto semi-árido (Tucker \& Wright 1990). Indica predominância de ação de processos não biogênicos no desenvolvimento de calcretes, tais como os freáticos.

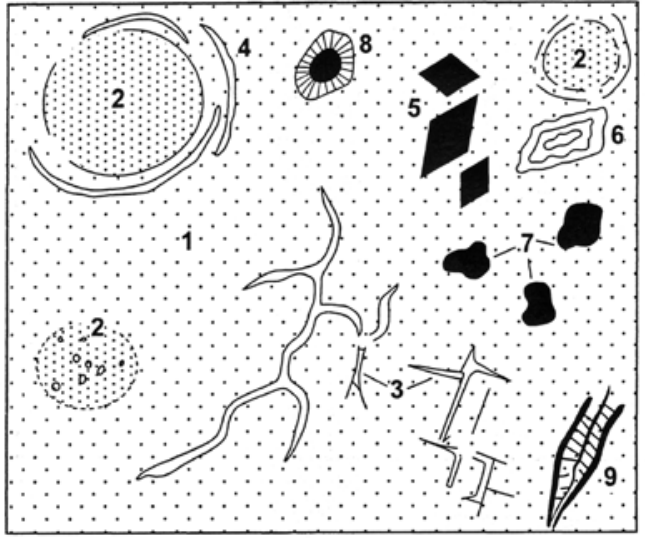

(a)

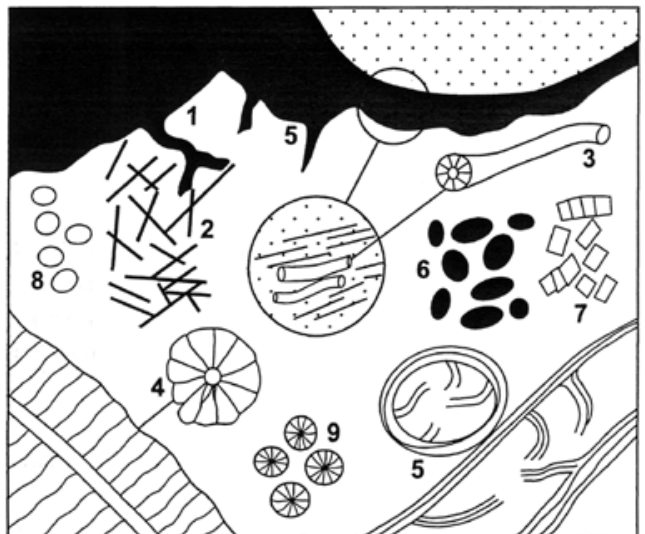

(b)

Figura 5 - Tipos de associações de microestruturas de calcretes (Wright \& Tucker 1991, Wrigth 2007). Convenções de alfa (quadro a): 1. matriz micrítica-microesparítica densa, 2. nódulos, 3. rachaduras complexas e crystallaria, 4. rachaduras circungranulares, 5. cristais romboédricos de calcita, 6. cristais de calcita corroídos, 7. grãos detriticos flutuantes (corroídos), 8. coroas aciculares de calcita em torno de grãos, 9. calcita deslocativa (p.ex. com micas); de beta (quadro b): 1. revestimento microbiano e oóides, 2. calcita acicular, 3. túbulos calcificados (principalmente fúngicos), 4. Microcodium, 5. trama septal alveolar, 6. pelotilhas calcificadas, 7. células vegetais calcificadas, 8. calciesferas (fúngicas, perithecium?), 9. esferulitos. 

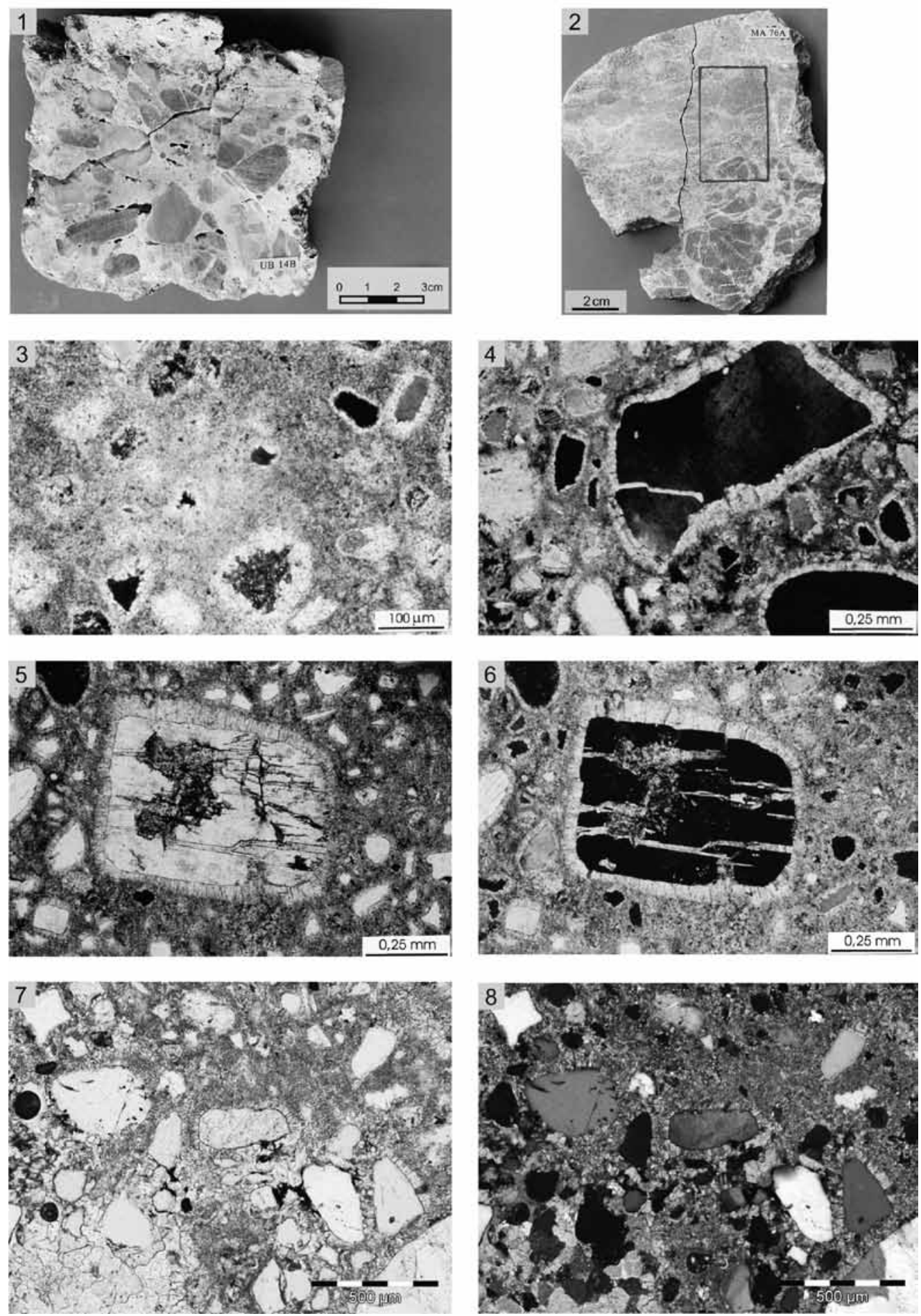

Figura 6 - 1) Arenito conglomerático imaturo intensamente cimentado, localmente chamado casco-de-burro. Notar feições de rompimento de clastos por processos de crescimento deslocativo (displacive) de calcita, que rompe clastos. Formação Ponte Alta, na Serra do Veadinho, Peirópolis (MG); 2) Arenito com textura favo-de-mel. Membro Echaporã, Serra do Mirante, SW de Marília; 3) Associação de microtexturas alfa, com feições de digestão do arcabouço siliciclástico, seção delgada, Formação São José do Rio Preto (SP), pol. cruzados; 4) Associação de microtexturas alfa, grãos com franja de calcita em paliçada; crescimento deslocativo (displacive) no grão maior. Seção delgada, Membro Echaporãa; 5 e 6) Associação de microtexturas alfa, cristalização em paliçadas, matriz micrítica/microesparítica. Notar substituição parcial do cristal de feldspato por calcita e corrosão de borda de outros grãos. Seção delgada, Membro Echaporã; 7 e 8) Associação de microtexturas alfa, intensa recristalização (calcita microesparítica a esparitica) grãos com franja de calcita (paliçada) flutuantes na matriz recristalizada, Membro Echaporã, Serra do Mirante, SW de Marilia, seções delgadas, pol. descruzados/cruzados. 

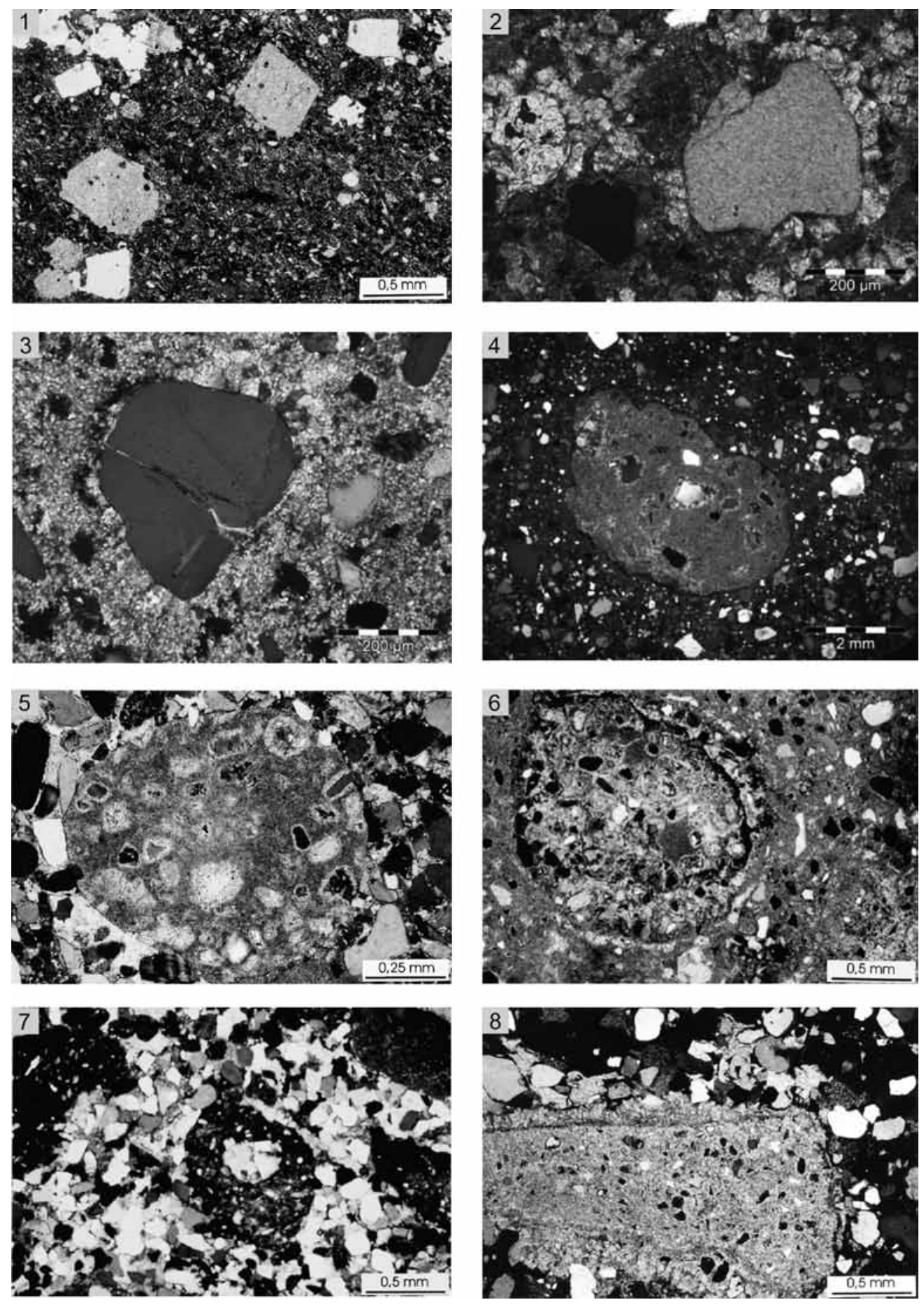

Figura 7 - 1) Calcita romboédrica poiquilotópica, em associação de microtexturas alfa. Seção delgada de crosta carbonática da Formação Araçatuba, das imediações da cidade homônima, pol. cruzados; 2) Grãos detríticos em calcita esparítica, associação de microtexturas alfa, seção delgada, Membro Echaporã, Monte Alto (SP), pol. cruzados; 3) associação de microtexturas alfa, seção delgada, pol. cruzados. Notar crescimento deslocativo de calcita no grão maior, Membro Echaporã, Marília; 4) intraclasto de calcrtete com associação de microtexturas alfa, em arenito imaturo com matriz argilosa, seção delgada, Membro Echaporã, Monte Alto (SP), pol. cruzados; 5) nódulo carbonático crescido em arcabouço siliciclástico (microtexturas alfa). Notar segmentos retilíneos do contorno (faces de crescimento), em avanço atestado por grãos parcialmente envolvidos nas zonas de limite dos cristais. Seção delgada, Formação São José do Rio Preto (SP), pol. cruzados; 6) Preenchimento de orificio de raiz por carbonato. Seção delgada, Membro Ponte Alta, de local a leste de Monte Alegre de Minas (MG), pol. descruzados; 7) Intraclasto de origem edáfica (seção de pedotúbulo?). Seção delgada, Formação Presidente Prudente, de local a oeste da cidade homônima, pol. cruzados; 8) Seção longitudinal de pedotúbulo(?) carbonático, provável preenchimento de molde de raiz por material mais fino e cimento carbonático. Arenito com estratificação cruzada, de barras fluviais arenosas. Formação São José do Rio Preto, pol. cruzados. 
A associação do tipo beta caracteriza-se por exibir diversas feições biogênicas relacionadas, sobretudo com ação de fungos, bactérias ou raízes (estruturas alveolares, septárias, revestimento de calcita acicular etc). Contrasta com a associação alfa, em que dominam as feições não pedogênicas e de recristalização. Na Formação Marília microtexturas da associação beta foram identificadas com menor freqüência, ocorrendo principalmente nas áreas marginais da bacia. Como feições de origem pedogênica vadosa foram identificadas na fração fina (plasma): a) franjas aciculares contornando grãos (paliçadas), revestimento de possível origem microbial e b) textura denominada skelsepic (Brewer 1976), constituída por revestimento de grãos por argilas com orientação paralela sistemática (Fig. 8.2). Os componentes detríticos frequentemente exibem também revestimento de argila associada a óxidos/hidróxidos de ferro.

Nas unidades que correspondem a depósitos mais marginais da bacia as litofácies de granulação mais grossa são mais freqüentes. Nelas é comum se encontrar intraclastos carbonáticos com microtexturas internas de processos pedogênicos vadosos (associação beta) ou de processos freáticos penecontemporâneos a eles. Embora menos comuns, tais processos de canibalismo de paleossolos são registrados também em outras unidades (Fig. 7.4 a 7.8, e 8.1). A erosão e ressedimentação (retrabalhamento) de horizontes edáficos são indicadas pela ocorrência de intraclastos argilosos com microtextura skelsepic (Fig. 8.2), nos membros Serra da Galga e Ponte Alta. Intraclastos com valvas de ostracodes articuladas, em matriz micrítica recristalizada, constituem outro registro de processos de retrabalhamento penecontemporâneo e canibalismo de depósitos de ambientes aquosos (Fig. 8.5), encontrados em calcretes do Membro Ponte Alta. A ocorrência de intraclastos argilosos com associação de microtexturas tipo alfa sugere terem coexistidos processos freáticos e vadosos ou paludiais, ou ainda tais interações modificadoras posteriores. Intraclastos constituídos por lama micrítica são mais comuns também nas unidades marginais da bacia. Ali a dinâmica sedimentar, com maior presença de água, propiciaria maior retrabalhamento de depósitos de lamas carbonáticas acumuladas em lagoas efêmeras de depressões interleques ou de contexto paludial.

Caracterização regional dos calcretes e discussão Calcrete é designação geral de acumulações terrestres próximas da superfície, predominante de carbonato de cálcio, que ocorrem em formas variadas: de pulverulento a nodular, laminar ou maciço (Wright 2007). Equivale ao termo caliche, mais utilizado na América do Norte. Os calcretes poder ser separados em dois tipos: pedogênicos ou vadosos, associados a desenvolvimento de perfis de solos e freáticos, relacionados com a zona saturada por águas subterrâneas, ricas em carbonato de cálcio, também conhecidos como groundwater calcretes. Estes últimos ocorrem como intervalos, em geral tabulares, formados pela introdução de carbonato de cálcio por cimentação e substituição controladas por nível freático bastante superficial, em solos, sedimentos ou rochas.

De modo geral, o estudo da micromorfologia dos calcretes da parte leste da Bacia Bauru indicou predomínio de feições de processos freáticos, sobretudo a ampla ocorrência da associação alfa nas amostras analisadas. Tal constatação sugere que o contexto genético freático foi dominante e/ou constituiu o último e talvez mais intenso evento. Neste último caso, possivelmente modificou feições pedogênicas vadosas anteriores.

Intraclastos carbonáticos, muito deles com texturas e feições de origem pedogênica vadosa são freqüentes nas amostras de calcretes analisadas dos membros Serra da Galga e Ponte Alta. Os fragmentos maiores permitiram identificar composição, microtexturas e microfósseis (Fig. 8.5) de contexto deposicional paludial e/ou lacustre penecontemporâneos.

Em termos litológicos os membros Ponte Alta e Serra da Galga diferenciam-se principalmente pela intensidade da cimentação carbonática. Porém, em termos texturais e mineralógicos, de associações de fácies, de relações estratigráficas, assim como posição na bacia, são muito semelhantes (Fernandes 1998). Quando se comparam com o Membro Echaporã, verifica-se que as litofácies pelíticas ou com mais matriz argilosa são relativamente mais freqüentes naqueles dois membros da Formação Marília, por serem depósitos mais proximais que os do Membro Echaporã. Maior freqüência de intraclastos micríticos nos membros Ponte Alta e Serra da Galga indica retrabalhamento de lamas, de maior quantidade e proximidade de lagoas de planícies de inundação ou de ambientes paludiais, contexto admitido para as partes mais marginais da bacia.

Revestimento (coating) de palygorskita e/ou sepiolita (Fig. 8.3, 8.4; 8.6 a 8.8) e possivelmente pseudomorfos de gipso indicam condições semi-áridas de sedimentação. A presença destes minerais corrobora análises faciológicas e paleogeográficas, que apontam condições semi-áridas a áridas durante a sedimentação na Bacia Bauru. Em regiões onde as chuvas são insuficientes para lixiviação de sais solúveis, tais como as semiáridas e desérticas formam-se os aridissolos. Estes solos apresentam horizontes calcários (cálcicos, petrocálcicos ou $B k$ ) rasos, em geral de menos de $1 \mathrm{~m}$ de profundidade. Os cimentos formam amplos estratos nodulares ou contínuos (Retallack 2001). Em termos de classificações de solos, portanto, os paleossolos e calcretes relacionados da Bacia Bauru são considerados aridissolos.

A disponibilidade de carbonato também deve ser considerada na discussão sobre a intensidade da cimentação. Os membros Ponte Alta e Serra da Galga correspondem aos depósitos mais proximais preservados da área de estudo. Desta forma, os mais próximos de fontes carbonáticas externas, tais como áreas de exposição de unidades paleozóicas da Bacia do Paraná, como a Fm. Irati ou rochas basálticas do substrato da bacia.

Em termos litofaciológicos, as seções carbonáticas de maior expressão da Bacia Bauru podem ser separadas em dois tipos principais, representadas por perfis aqui denominados de Echaporã e Ponte Alta (Fig. 2). Tais tipos são definidos, sobretudo, por suas características associações faciológicas, decorrentes de sua posição paleogeográfica. No primeiro predominam 

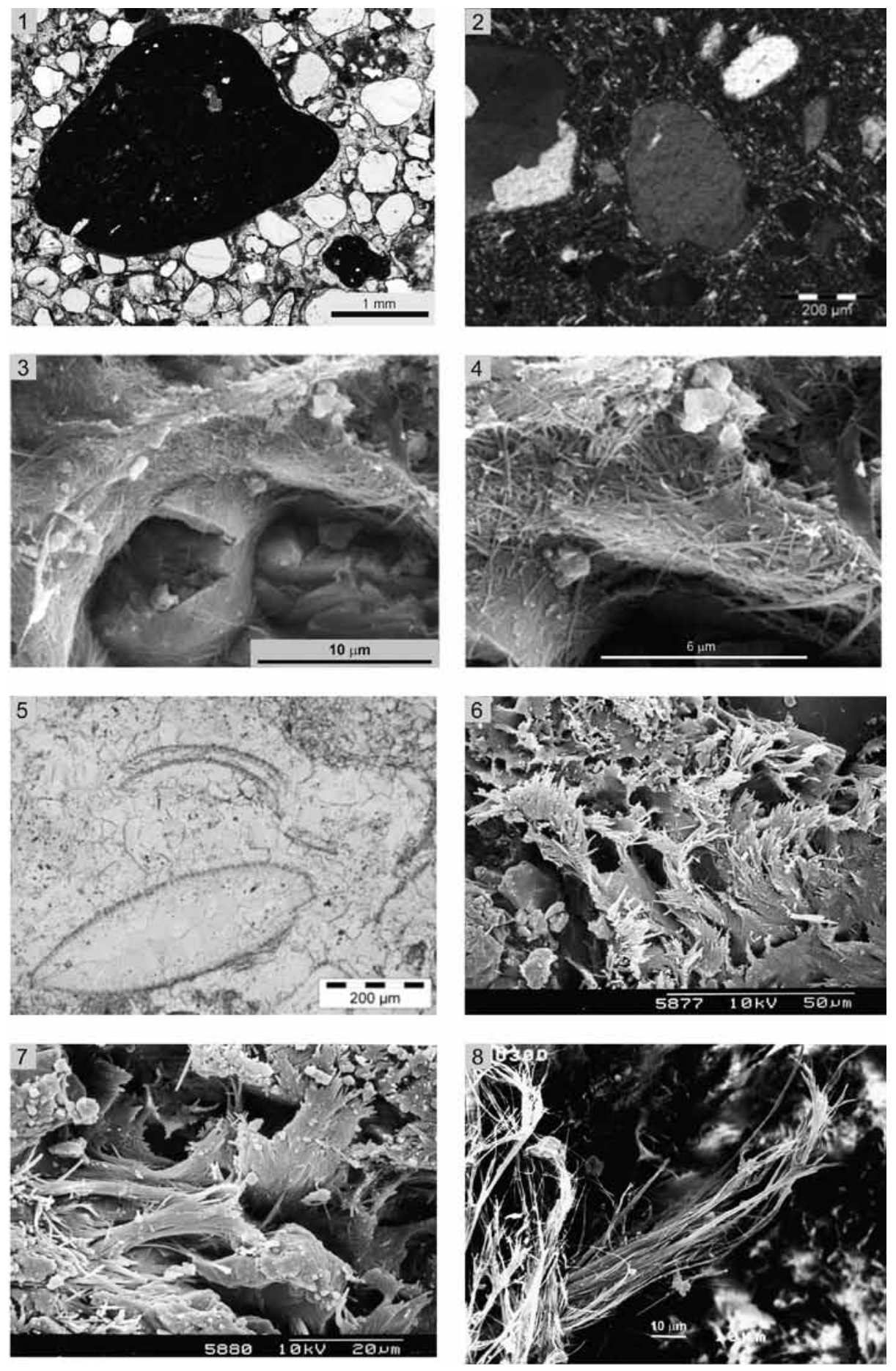

Figura 8 - 1) Intraclasto argiloso pedogênico(?) em matriz lama carbonática recristalizandose em textura esparítica, Membro Echaporã, Serra do Bonito, Campina Verde (MG); seção delgada, pol. descruzados; 2) matriz argilosa com microtextura de plasma skelsepic (contornado grãos) e lattisepic (em ângulo reto), tipo beta, indicativa de pedogênese vadosa ou paludial, Membro Serra da Galga, Serra do Veadinho, Peirópolis (MG), seção delgada, pol. cruzados; 3 e 4) Revestimento de poros por calcita e palygorsita ou sepiolita, de arenito intensamente cimentado, Membro Ponte Alta, BR 050/km 149, NW de Uberaba (MG), imagem de MEV (elétrons secundários); 5) ostracodes em intraclasto de calcita esparítica, indicativos de origem lacustre ou paludial, redepositado e modificado por processos freáticos posteriores, Arenito conglomerático intensamente cimentado por carbonato; de barras arenosas cascaIhentas; Membro Ponte Alta, Serra do Veadinho, Peirópolis (MG), seção delgada, pol. descruzados; 6 e 7) palygorskita em revestimento de poros de arenito do Membro Ponte Alta, BR 050/km 149, NW de Uberaba (MG). Micrografia de MEV (elétrons secundários), indicativa de contexto semi-árido; 8) palygorskita, revestimento de poros de arenito do Membro Ponte Alta (Litofácies Rubião Jr.), oeste de Botucatu (SP). Micrografia de MEV (elétrons secundários). 
depósitos de lençóis de areia com algumas planícies fluviais rasas e lagoas efêmeras, enquanto que o segundo formou-se em contexto de leques aluviais (Fig. 9).

Por outro lado, os resultados da análise petrológica (petrofácies e microtexturas identificadas), revelaram freqüente sobreposição de eventos de cimentação carbonática, de origens pedogenética vadosa e freática. Associando-se as características petrológicas e o contexto deposicional (litofaciológico), tendo-se também em conta a escala regional da pesquisa, são propostos três contextos principais de desenvolvimento dos calcretes da Formação Marília:

PEDOGENÉTICO PERIFÉRICO (Pp) Atuaram processos pedogenéticos iniciais, vadosos e paludiais, com formação de perfis de solos pouco evoluídos/desenvolvidos. Reflete condições de maior aporte e rápida deposição de sedimentos, em depósitos de leques aluviais e corpos d'água efêmeros associados. Nestes ambientes o desenvolvimento de paleossolos estaria relacionado a intervalos de tempo relativamente curtos de baixa ou nenhuma sedimentação. Nos horizontes de calcretes formados neste contexto predomina a associação beta. Estas seriam as condições mais comuns nas regiões periféricas da bacia, registrada, por exemplo, nos perfis tipo Ponte Alta, na região de Uberaba, MG;

PEDOGENÉTICO INTERIOR (Pi) Atuaram processos pedogenéticos vadosos iniciais, relativamente mais duradouros que os do contexto Pm, sem todavia desenvolver perfis de solos maduros. Os horizontes de calcretes formaram-se em depósitos arenosos interiores, durante períodos de baixa ou nenhuma sedimentação. Nestes horizontes calcificados são comuns as microtexturas da associação beta, tais como revestimentos de argila e óxidos/hidróxidos de ferro. Trata-se do contexto característico do interior da bacia, onde os calcretes desenvolveram-se em perfis tipo Echaporã. Por exemplo, como expostas nas regiões de Campina Verde (MG), Monte Alto, Agudos, Bauru (SP); e

FREÁTICO (F) A ação de processos relacionados ao nível freático raso foram dominantes, e desenvolveram textura cristalina micrítica a esparítica (eventual recristalização da matriz), que provavelmente destruiu eventuais microfeições originais da associação beta, desenvolvidas anteriormente nos contextos Pm e Pi. Como resultado final da sobreposição de processos a associação alfa é dominante. Assim formaram os calcretes do interior da bacia, dos perfis Echaporã nas regiões de

\section{Tipo Echaporã}

(lençóis de areia)

contexto freático/fluvial
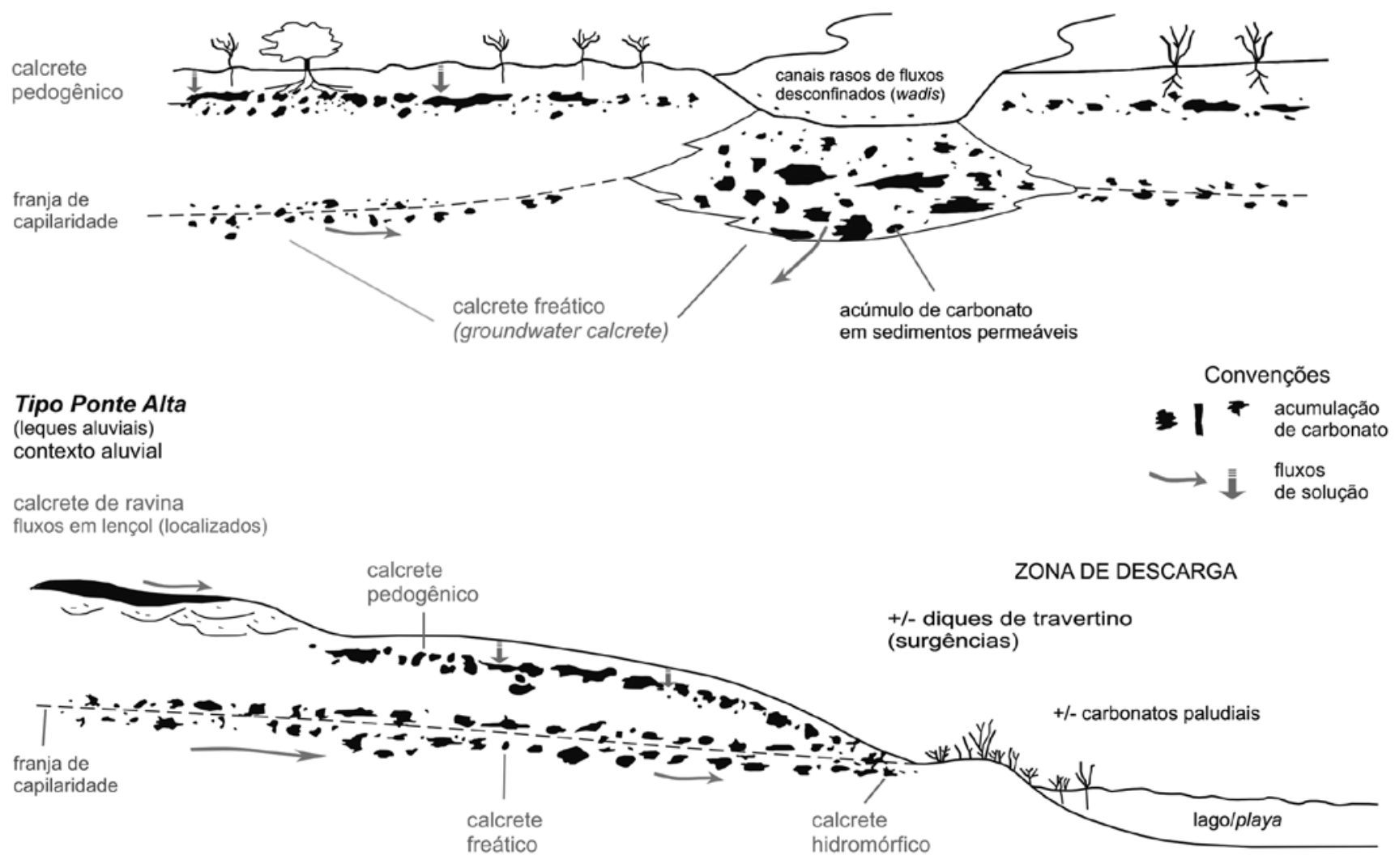

Figura 9 - Tipos principais de calcretes da Formação Marília, de acordo com contexto genético original, designados como Ponte Alta e Echaporã (Adaptado de modelo de Wright 2007). 
Marília e Echaporã (SP).

Na formação do perfil tipo Echaporã predominaram processos de concentração de carbonatos em intervalos de taxa de sedimentação baixa. Foram condições dominantes no interior da bacia, próximo a fluxos fluviais entrelaçados efêmeros que sulcavam lençóis de areia, em clima semi-árido. Os processos pedogenéticos vadosos foram mais efetivos nas planícies de inundação e terraços $(\mathrm{Pi})$, os freáticos nos canais e áreas baixas, próximas da parte superior da zona saturada (F). Os calcretes do tipo Echaporã apresentam-se em estratos de aspecto maciço, com horizontes de cimentação carbonática com texturas maciça a difusa (mosqueada), nodulares e de crostas carbonáticas, dispostos em sucessões verticais características, de até cerca de um metro de espessura. Parte de tais sucessões podem eventualmente corresponder a antigos perfis de solos, como no clássico modelo de Esteban \& Klappa (1983). Hoje porém constituem sucessões de estratos com intensa cimentação carbonática de características genéticas freáticas. Em algumas regiões semi-áridas a áridas verifica-se extensiva precipitação de carbonato em zonas freáticas rasas, que geram extensos corpos de carbonato autigênico com muitas características em comum com calcretes pedogênicos. Denominados freáticos (groundwater calcretes), eles podem exibir relações complexas com formas pedogênicas e com alguns tipos de calcários paludiais (Wright 2007).

Calcretes e inversão de relevo $\mathrm{Na}$ Bacia Bauru, a Formação Marília é a unidade com desenvolvimento de intervalos mais espessos de calcretes nodulares a maciços. Eles sustentam relevo de mesetas nas regiões de Marília e Echaporã, assim como no Triângulo Mineiro entre Uberaba e região de Campina Verde. A origem freática dominante destes calcretes é indicada por características petrográficas. Quando analisada em escala regional, a formação exibe área com contorno de aspecto dendrítico em planta (Fig. 1 e 10).

A configuração dendriforme do relevo de platôs estritos e longos, sustentados pelos arenitos calcificados do Membro Echaporã, pode ser explicada pela elaboração da paisagem atual por inversão de relevo (Fig. 11). Diversos exemplos de inversão de relevo associada a antigas aluviões cimentadas por carbonatos são citados (e.g. Pain \& Ollier 1995, Wright 2007). Em regiões semi-áridas a deposição de carbonato de cálcio frequentemente associa-se com linhas de drenagem e planícies aluviais. Miller (1937) descreveu exemplo de inversão de relevo por cimentação carbonática ao longo de linhas de drenagem em área de mais de $10.000 \mathrm{~km}^{2}$, no oeste da Arábia Saudita. Tal área tem ordem de grandeza semelhante à de exposição atual da Formação Marília.

Desta forma a área de ocorrência atual daquela unidade provavelmente reflete a paleogeografia de um sistema de drenagem regional conseqüente, que rumava para oeste, constituído por fluxos aquosos provenientes das bordas. Rumavam para o interior da bacia até dispersarem-se em monótonas planícies de lençóis de areia mais internos, em rasos e desconfinados. Na parte oriental da bacia, o que restou dos depósitos proximais que alimentaram os lençóis de areia interiores está hoje preservado principal-

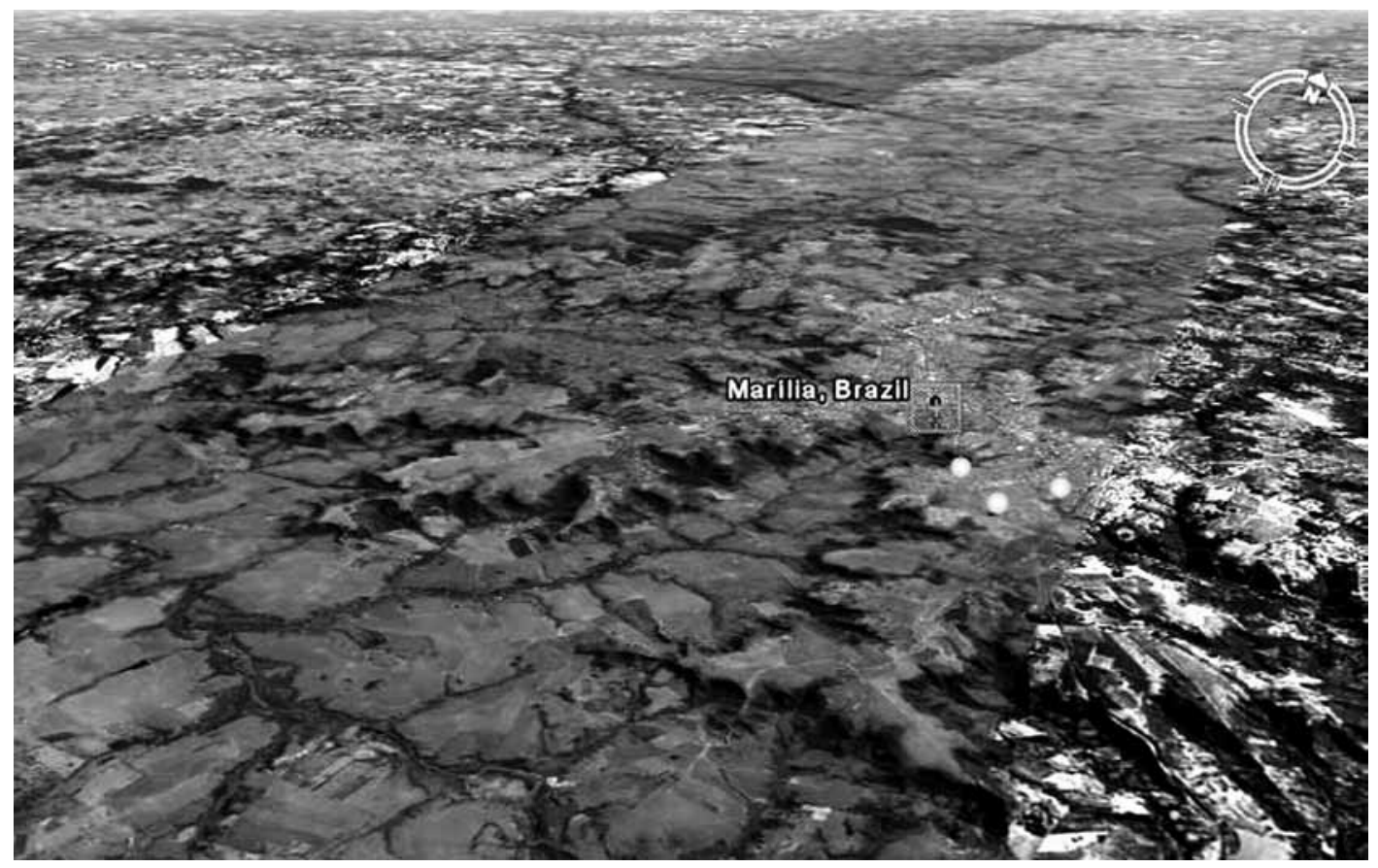

Figura 10 - Configuração dendriforme do relevo de platôs estreitos e longos, sustentados pelos arenitos calcificados da Formação Marília. A elaboração da paisagem se deu por inversão de relevo do relevo. Imagem obtida em Google Earth (http://earth.google.com/intl/pt/), acesso em $8 / 8 / 2007,16: 24 h$. 


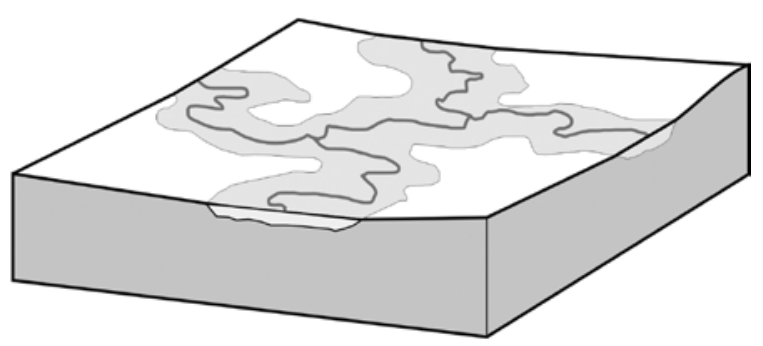

b

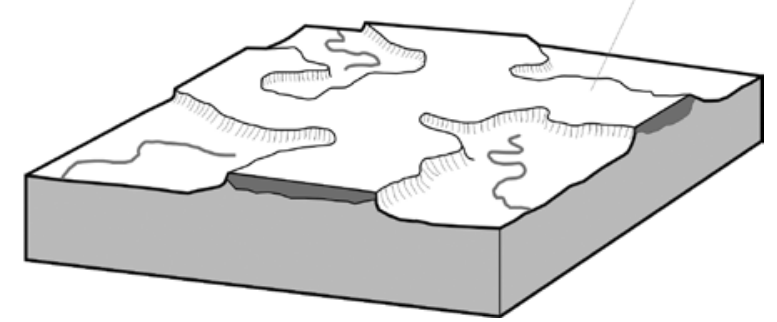

Figura 11 - Modelo de configuração do relevo atual associado à Formação Marília: a. formação de horizontes de calcretes pedogênicos e freáticos em áreas mais baixas e úmidas do terreno, $b$. paisagem atual elaborada segundo a resistência diferenciada à erosão dos depósitos cimentados, por inversão de relevo (baseado em Pain \& Ollier 1995).

mente na região de Uberaba (MG) - membros Serra da Galga e Ponte Alta-, e em ocorrência restrita próxima de Botucatu, em São Paulo (Litofácies Rubião Junior).

CONCLUSÕES Em toda a parte oriental da Bacia Bauru ocorrem feições de processos pedogênicos associados com concentração de carbonatos, tais como moldes de raízes em litofácies pelíticas de ambientes mais úmidos, paludiais, lagoas ou planícies fluviais de inundação. Todavia, as unidades com cimentação mais expressiva, que constituem horizontes mais espessos de calcretes, ocorrem nas zonas mais externas da área de exposição atual da bacia.

A Formação Marília é a que apresenta o maior volume de calcretes, se considerarmos área de ocorrência e espessura. Tal unidade litoestratigráfica é constituída por arenitos com cimentação carbonática em graus variados, de pulverulentos a nodulares ou, mais intensa, quando formam crostas e estratos tabulares maciços de espessura métrica. Em escala de bacia, as associações de fácies em que mais se desenvolveram os calcretes podem ser representadas por dois tipos extremos principais, relacionados à paleogeografia e, portanto, ao contexto deposicional (marginal ou interior).

O primeiro tipo, aqui denominado Ponte Alta, formou-se em depósitos de contexto de leques aluviais marginais. Onde houve maior quantidade de água disponível, maior variação de energia dos agentes de transporte e nas condições deposicionais. Neste contexto de leques coalescentes coexistiram lagoas efêmeras represadas entre lobos, fluxos fluviais rasos e enxurradas de grande carga de fundo, assim como zonas paludiais nas partes baixas distais. Os depósitos são constituídos conglomerados imaturos com intercalações arenosas e pelíticas. Em termos litoestratigráficos este primeiro tipo corresponde aos membros Serra da Galga e Ponte Alta. O clima semi-árido dominante durante a sedimentação é atestado pelas características texturais e mineralógicas dos depósitos. Neste contexto predominam paleossolos carbonáticos pouco desenvolvidos.

O segundo tipo, designado Echaporã, desenvolveu-se em depósitos arenosos eólicos interiores, de amplos lençóis de areia e suaves depressões com presença temporária de água. Entre os estratos arenosos de aspecto maciço às vezes ocorrem delgados intervalos conglomeráticos, formados por nódulos carbonáticos e raros clastos silicosos, alguns deles, ventifactos. Em geral, tais acumulações de clastos ocorrem no topo ou pouco acima de crostas carbonáticas. Provavelmente formaram-se por deflação eólica e/ou de remobilização por enxurradas e fluxos em lençol pouco duradouros (wadis). Em termos litoestratigráficos este segundo tipo descrito corresponde ao Membro Echaporã.

$\mathrm{O}$ estudo petrológico dos intervalos mais cimentados por carbonatos (calcretes) apontou clara predominância da associação de microtexturas do tipo alfa nas seções analisadas, independente de sua origem. Tal associação é caracterizada sobretudo por apresentar grãos flutuando na matriz carbonática, muita vezes recristalizada (microesparítica a esparítica), com feições de corrosão de grãos detríticos (e.g. quartzo e feldspatos) e calcita romboédrica. Nestas fácies identificaramse possíveis feições de dolomitização. A associação alfa relaciona-se com predominância de processos não biogênicos no desenvolvimento de calcretes, tais como os freáticos. Estes provavelmente foram os mais intensos e teriam sido do último e/ou do mais importante evento na formação dos calcretes estudados. Em conseqüência, a cimentação freática provavelmente modificou eventuais feições edáficas anteriores. A presença de palygorskita ou sepiolita em amostras com microtexturas da associação beta, provenientes da porção nordeste da bacia indica condições semi-áridas a áridas durante a sedimentação, concordante com o contexto paleoambiental concebido para a Bacia Bauru.

De modo geral pode-se afirmar que a análise de características petrográficas e microtexturas dos calcretes da Formação Marília indicou freqüente sobreposição de efeitos de processos pedogênicos vadosos e freáticos. Todavia, os últimos predominam e possivelmente modificaram registros iniciais de processos pedogênicos. Em geral, pouco evoluídos, foram identificados, sobretudo, por feições preservadas em intraclastos carbonáticos encontrados nas frações mais grossas. Com base nas características petrológicas, contexto deposicional (litofaciológico) e a escala regional da pesquisa, são propostos três contextos principais de desenvolvimento dos calcretes da Formação Marília.

No primeiro, pedogenético periférico $(\mathbf{P p})$, pre- 
dominaram processos pedogenéticos vadosos e paludiais, perfis de solos pouco desenvolvidos, em condições de freqüente aporte e rápida sedimentação (depósitos de leques aluviais e corpos d'água efêmeros associados). Estas condições foram mais comuns na periferia da bacia, hoje preservada em perfis tipo Ponte Alta, em Minas Gerais. Nos registros deste contexto verificou-se maior freqüência da associação de microtexturas beta.

No contexto pedogenético interior $(\mathbf{P i})$ atuaram processos pedogenéticos vadosos iniciais, relativamente mais duradouros que os do contexto Pp, embora sem desenvolver perfis de solos maduros. Os calcretes formaram-se em depósitos arenosos interiores de lençóis de areia, em intervalos de baixa ou nenhuma sedimentação. Nos calcretes predominam microtexturas da associação beta, revestimentos de grãos por argilas e óxidos/hidróxidos de ferro. Este contexto foi característico do interior da bacia, registrado em perfis tipo Echaporã, como se verifica, por exemplo, nas regiões de Campina Verde (MG), Monte Alto, Agudos, Bauru (SP).

$\mathrm{O}$ terceiro contexto genético dos calcretes da Formação Marília, freático $(\mathbf{F})$, caracteriza-se por ação principal de processos relacionados com nível freático raso. Houve intenso desenvolvimento de textura cristalina micrítica a esparítica, que provavelmente destruiu eventuais microfeições originais da associação beta, desenvolvidas anteriormente em contextos Pp e Pi. A sobreposição de processos freáticos determinou assim o predomínio da associação de microtexturas alfa, como característica petrográfica. Neste contexto formaram-se os calcretes do interior da bacia, dos perfis Echaporã, nas regiões de Marília e Echaporã (SP).

$\mathrm{O}$ contorno atual da área de exposição da Formação Marília, formado por relevo de platôs estreitos e longos, tem configuração dendrítica em planta. A paisagem regional de mesetas escarpadas é resultado da maior resistência à erosão dos arenitos cimentados. Os calcretes da Formação Marília exibem características petrográficas de predomínio de processos genéticos freáticos. Portanto, tais características sugerem que a elaboração da paisagem atual deu-se por processo geomorfológico denominado inversão de relevo. As zonas de arenitos calcificados, por isto mais resistentes à erosão, hoje sustentam relevo mais alto. Foram outrora partes baixas do terreno, onde se deu a cimentação carbonática freática mais intensa. Nos depósitos de leques aluviais marginais se formaram calcretes do tipo Ponte Alta. Para o interior da bacia, nos lençóis de areia com intercalações de depósitos de fluxos fluviais desconfinados e lagoas efêmeras, se desenvolveram os calcretes do tipo Echaporã.

Agradecimentos $\mathrm{O}$ autor agradece à Profa. Dra. Ana Maria Alonso Zarza, do Departamento de Petrología y Geoquímica da Universidad Complutense de Madrid, pela dedicada cooperação científica em dois estágios pós-doutorais realizados naquela universidade. Agradece também à Coordenação de Aperfeiçoamento de Pessoal de Nível Superior - CAPES, pelo auxílio financeiro (processo PDEE 3989-07-0) e à Fundación Carolina pela bolsa do programa Movilidad de profesores de universidades públicas brasileñas (2009) que tornaram possíveis tais estágios e demais ações de cooperação científica. É grato ao Conselho Nacional de Desenvolvimento Científico e Tecnológico pelo apoio à pesquisa (CNPq Universal 411717/2007-0) e bolsa de Produtividade em Pesquisa do CNPq - Nível 2. Agradece, finalmente, aos pareceristas da revista pela cuidadosa análise e sugestões para aprimoramento deste artigo.

\section{Referências}

Almeida F.F.M. de \& Barbosa O. 1953. Geologia das quadrículas Piracicaba e Rio Claro, Estado de São Paulo. Boletim DGM/DNPM, 143:1-96.

Alonzo-Zarza A.M. 2003. Palaeoenvironmental significance of palustrine carbonates and calcretes in the geological record. Earth Sciences Reviews, 60:261-298.

Basilici G., Ladeira F.S.B., Dalbo P.F.F. 2007. Aeolian/fluvial and paleosol climatic sequences in an ancient sand sheet: Marília Formation, Late Cretaceous, Bacia Bauru, Brazil. In: International Association of Sedimentologists, Meeting, 25, Patras (Grécia), Abstracts Book. p. 49.

Brewer R. 1976. Fabric and mineral analysis of soils. New York, Krieger, 482 p.

Capilla R. \& Azevedo S.A.K. 1996. O Cretáceo da região de Uberaba - Paleovertebrados. Roteiro de excursão. Rio de Janeiro, Museu Nacional/UFRJ (Projeto Dinossauros do Brasil), 41 p.

Esteban M. \& Klappa C.F. 1983. Subaerial exposure environment. In: Schole P.A., Bebout D.G. \& Moore C.H. (eds.). Carbonate depositional environments. Tulsa, The American Association of Petroleum Geologists (Memoir 33), p.1-96.
Fernandes L.A. 1998. Estratigrafia e evolução geológica da parte oriental da Bacia Bauru (Ks, Brasil). 216p. Tese de Doutoramento, Instituto de Geociências da Universidade de São Paulo, 3 mapas.

Fernandes L.A. \& Basilici G. 2009. Transition of ephemeral palustrine to aeolian deposits in arid-semi-arid environment of the intracratonic Bauru Basin (Upper Cretaceous, Brazil). Creatceous Research, 30:605-614.

Fernandes L.A. \& Coimbra A.M. 1996. A Bacia Bauru (Cretáceo Superior, Brasil). Anais da Academia Brasileira de Ciências, 68(2):195-205.

Fernandes L.A \& Coimbra A.M. 2000. The Late Cretaceous Caiuá Desert (Bauru Basin, Brazil). In: IUGS, Intern. Geol. Cong., 31, Rio de Janeiro (Brasil). Abstracts, (CDRom, General Symposia, 3.6).

Fernandes L.A., Coimbra A.M., Brandt Neto M. 1993. Silicificação hidrotermal neocretácea na porção meridional da Bacia Bauru. Revista do Instituto Geológico, 14(2):1926.

Fernandes L.A., Sedor F.A., Silva R. C., Silva L.R., Azevedo A.A., Siqueira A.G. 2009. Sítio Icnofósseis da Usina Porto Primavera, SP. Sitios Geológicos e Paleontológi- 
cos do Brasil, vol. II, cap. 13, p. 479-488. Disponível em http://e-groups.unb.br/ig/sigep/propostas/Icnofosseis Usina_PortoPrimavera_SP.htm, acesso em 23/3/2010).

Goldberg K. \& Garcia A.J.V. 1995. Faciologia dos calcários do Grupo Bauru na região de Uberaba (MG). Geociências, 14(2):121-131.

Gómez-Gras D. \& Alonso-Zarza A.M. 2003. Reworked calcretes: their significance in the reconstruction of alluvial sequences (Permian and Triassic, Minorca, Balearic Islands, Spain). Sedimentary Geology, 158:299-319.

Hasui Y. 1969. O Cretáceo do oeste mineiro. Boletim da Sociedade Brasileira de Geologia, 18(1):38-56.

Klappa C.F. 1980. Rhizoliths in terrestrial carbonates: classification, recognition, genesis and significance. Sedimentology, 27:613-629.

Kraus M.J. 1999. Paleosols in clastic sedimentary rocks: their geologic applications. Earth Sciences Reviews, 47:41-70.

Loope D.B. 1988. Rhizoliths in ancient eolianites. Sedimentary Geology, 56:301-314.

Mason J.A., Nater E.A., Zanner C.W., Bell J.C. 1999. A new model of topographic effects on the distribution of loess. Geomorphology, 28:223-236.

Miall A.D. 1996. The geology of fluvial deposits. Sedimentary facies, basin analysis and petroleum geology. New York, Spriger-Verlag, 582 p.

Miller R.P. 1937. Drainage lines in bas-relief. Journal of Geology, 45:432-438.

Pain C.F. \& Ollier C.D. 1995. Inversion of relief - a component of landscape evolution. Geomorphology, 12:151165.

Retallack G.J. 1988. Field recognition of paleosols. In: Rein- hardt J. \& Sigleo W.R. (eds.) Paleosols and Weathering Through Geologic Time: Principles and Applications. Geological Society of America (Special Paper, 216), p.1-20.

Retallack G.J. 2001. Soils of the Past: an Introduction to Paleopedology. Oxford, Blackwell Science, $404 \mathrm{p}$.

Setzer J. 1943. Os solos do nordeste. São Paulo, Secretaria da Agricultura, Indústria e Comércio do Estado de São Paulo, $15 \mathrm{p}$.

Setzer J. 1948. Algumas contribuições geológicas dos estudos de solos realizados no estado de São Paulo. Revista Brasileira de Geografia, 10(1):41-104.

Silva R.B., Etchebehere M.L.C., Saad A.R. 1994. Groundwater calcretes: uma interpretação alternativa para os calcários da Formação Marília no Triângulo Mineiro. In: Universidade Estadual Paulista, Simp. sobre o Cretáceo do Brasil, 3, Boletim. p.85-89.

Suguio K. \& Barcelos J.H. 1983. Calcretes of the Bauru Group (Cretaceous), Brazil: petrology and geological significance. Boletim IG-USP, 14:31-47.

Tucker M.E. \& Wright V.P. 1990. Carbonate Sedimentology. London, Blackwell Scientific Publications Ltd., 482 p.

Wright V.P. 2007. Calcretes. In: Nash D.J. \& McLaren S.J. (eds.) Calcretes in Geochemical Sediments and Landscapes. Oxford, Blackwell, p:10-45.

Wright V.P. \& Tucker M.E. (eds.) 1991. Calcretes: an introduction. International Association of Sedimentologists Reprint Series, 2:1-22.

Manuscrito ID 11731 Submetido em 09 de julho de 2008 Aceito em 09 de fevereiro de 2010 